[Agr. Biol. Chem., Vol. 34, No. 11, p. 1618 1624, 1970]

\title{
An Oligogalacturonate Transeliminase from Erwinia aroideae
}

\author{
By Chitoshi Hatanaka and Junjiro Ozawa \\ Institute for Agricultural and Biological Sciences, Okayama University, Kurashiki \\ Received February 21, 1970
}

\begin{abstract}
An oligogalacturonate transeliminase (oligogalacturonate lyase) was isolated from the cell extract of Enwinia aroideae. This enzyme was purified by adsorption on columns of calcium phosphate on cellulose, treatment with Duolite CS-101 and DEAE-cellulose chromatography. It cleaved the first glycosidic linkage from the reducing end of the substrate molecule, the product found in the reaction mixture being 4-deoxy-5-keto-D-fructuronic acid. It attacked preferentially the short-chain uronides. The enzyme preparation showed only a slight activity toward high molecular pectic acid. The $\mathrm{pH}$ optimum was at 7.0. Calcium ion had no effect on the enzyme activity. Unsaturated oligogalacturonates were degraded more rapidly than oligogalacturonates having no unsaturated galacturonic acid residue. For this reason it might be appropriate to call this enzyme unsaturated oligogalacturonate transeliminase.
\end{abstract}

Earlier work ${ }^{11}$ from our laboratories suggested the presence of two different exo-pectate transeliminases in Erwinia ariodeae. Later, one of them was isolated and characterized., ${ }^{2,31}$ This enzyme breaks the second glycosidic linkage from the reducing end of the substrate molecule, liberating 4,5-unsaturated digalacturonic acid. The presence of an exo-pectate transeliminase of this type was demonstrated also in Clostridium multifermentans by Macmillan et al. ${ }^{4,51}$

In the present study the other exo-pectate transeliminase was purified. Although this enzyme may have a slight activity toward high molecular pectic acid, it preferentially attacks the short-chain uronides. Therefore,

1) K. Okamoto, C. Hatanaka and J. Ozawa, Agr. Biol. Chem., 27, 596 (1963).

2) K. Okamoto, C. Hatanaka and J. Ozawa, ibid., 28331 (1964).

3) K. Okamoto, C. Hatanaka and J. Ozawa, Nippon Nogeikagaku Kaishi, 38, 237 (1964).

4) J. D. Macmillan and R. H. Vaughn, Biochemistry, 3, 564 (1964).

5) J. D. Macmillan, H. J. Phaff and R. H. Vaughn, ibid., 3, 572 (1964). it is described under the name oligogalacturonate transeliminase. The purification and characterization of this enzyme is reported in this paper.

\section{MATERIALS AND METHODS}

Preparation of crude enzyme solution. The conditions of culture of Erwinia aroideae used in this study have been described in 1 previous paper. ${ }^{2}$ The culture $(1200 \mathrm{ml})$ was filtered through coarse filter paper on a Büchner funnel with suction, and the cells were harvested by centrifugation and washed twice with distilled water. The wet weight of the washed cells was about $34 \mathrm{~g}$. The cells were suspended in $340 \mathrm{ml}$ of $0.02 \mathrm{M}$ phosphate buffer, $\mathrm{pH} 7.0$, containing $6.8 \mathrm{ml}$ of toluene. After $16 \mathrm{hr}$ shaking at $30^{\circ} \mathrm{C}$, the super natant was collected by centrifugation and dialyzed against $0.005 \mathrm{M}$ phosphate buffer, $\mathrm{pH} 7.0$, for 3 days. The dialyzed solution (preparation No. 1) was added to a column $(4 \times 5 \mathrm{~cm})$ of calcium phosphate on cellu* lose, ${ }^{6 !}$ previously equilibrated with $0.005 \mathrm{M}$ phosphate buffer, pH 7.0 , followed by $300 \mathrm{ml}$ of the same buffer for washing. The column was then eluted with 0.05 .

6) V. E. Price and R. E. Greenfield, J. Biol. Chem. 209, 363 (1954). 
M phosphate buffer, $\mathrm{pH} 7.0$. The fraction giving a xanthoprotein test was collected and dialyzed against $0.01 \mathrm{M}$ phosphate buffer, $\mathrm{pH} 7.0$, for 2 days. The dialyzed solution (preparation No. 2) was passed through a Duolite CS-101 column $(4 \times 20 \mathrm{~cm})$ which had been previously equilibrated with $0.01 \mathrm{M}$ phosphate buffer, $\mathrm{pH}$ 7.0. The effluent solution was used as crude enzyme solution (preparation No. 3).

Preparation of substrates. All substrates except 4,5unsaturated digalacturonic acid ${ }^{7}$ and 4-deoxy-5-ketoD-fructuronic acid ${ }^{81}$ were prepared as described previously.9)

Assay of enzyme activity. Unless otherwise stated, the reaction mixture used for the assay of enzyme activity contained $0.1 \%$ substrate, $0.04 \mathrm{M}$ phosphate buffer, $\mathrm{pH} 7.0$, and a proper dilution of the enzyme. The reaction mixture was incubated at $35^{\circ} \mathrm{C}$. Enzyme activity was determined by measuring the increase in the reducing power or by estimating the amount of the degradation product, 4-deoxy-5-keto-D-fructuronic acid. For the determination of the units of the oligogalacturonate transeliminase, 4,5-unsaturated digalacturonic acid was used as the substrate. In this case the activity was determined by measuring the decrease in optical density at $232 \mathrm{~m} \mu$. By using the molar extinction coefficient of 4,5-unsaturated digalacturonic acid $(4700)^{91}$ the optical density values can be converted into moles of unsaturated bonds split. A unit is defined as that amount of enzyme required to split $1 \mu$ mole of bonds per hour.

Analytical methods. The reducing power of the reaction mixture was determined by a modification ${ }^{10}$ of the Willstätter-Schudel method. The amount of 4-deoxy-5-keto-D-fructuronic acid in the reaction mixture was determined according to the thiobarbituric acid assay of Weissbach and Hurwitz ${ }^{11}$ in which the periodate oxidation was carried out at $0^{\circ} \mathrm{C}$ for $30 \mathrm{~min}$. As shown in Fig. 1, the amount of color produced in the thiobarbituric acid test was found to be greatly affected by temperature of periodate oxidation. Moreover, the sensitivity of the test seems to be seriously affected by the structure of sugars. When

7) C. Hatanaka and J. Ozawa, Nippon Nogeikagaku Kaishi, 43, 77 (1969).

8) C. Hatanaka and J. Ozawa, ibid., 43, 139 (1969).

9) C. Hatanaka and J. Ozawa, ibid., 43, 764 (1969),

10) C. Hatanaka, ibid., 41, 448 (1967).

11) A. Weissbach and J. Hurwitz, J. Biol. Chem., 234, 705 (1959).

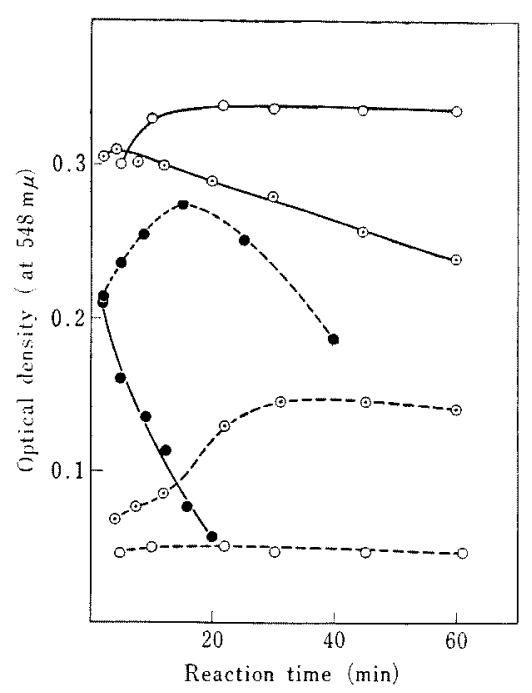

FIG. 1. Effect of Temperature of Periodate Oxidation on the Color Production in the Thiobarbituric Acid Test of 4-Deoxy-5-keto-D-fructuronic Acid and 4,5-Unsaturated Digalacturonic Acid.

$\bigcirc 0^{\circ} \mathrm{C}, \odot 30^{\circ} \mathrm{C}, \quad 80^{\circ} \mathrm{C},-4$-deoxy-5-keto-Dfructuronic acid (ca. $0.05 \mathrm{mM}$ ), -.-4,5-unsaturated digalacturonic acid (ca. $0.5 \mathrm{~mm}$ )

periodate oxidation was carried out under the above conditions, the amount of color produced from 4-deoxy 5-keto-D-fructuronic acid was about 70 times as much as that from 4,5-unsaturated digalacturonic acid (Fig. 1).

Protein was determined by the Folin-Lowry method, as modified by Hagiwara.12,

Paper chromatography was done in an ascending manner on Toyo Roshi No. 52 paper. The solvent system used was $n$-butanol-acetic acid-water $(5: 2: 3)$. Spots were made visible by spraying with anilinehydrochloric acid (for sugars), bromophenol blue (for uronic acids) and quinine sulfate reagent ${ }^{13\}}$ (for unsaturated uronides).

\section{RESULTS}

\section{Purification of oligogalacturonate transeliminase} The crude enzyme solution (preparation No.

12) B. Hagiwara, "Koso Kenkyuho,' ed. by $\mathrm{S}$. Akabori, Asakura Shoten, 1, 166 (1955).

13) R. D. Edstrom and H.J. Phaff, J. Biol. Chem., 239, 2403 (1964). 


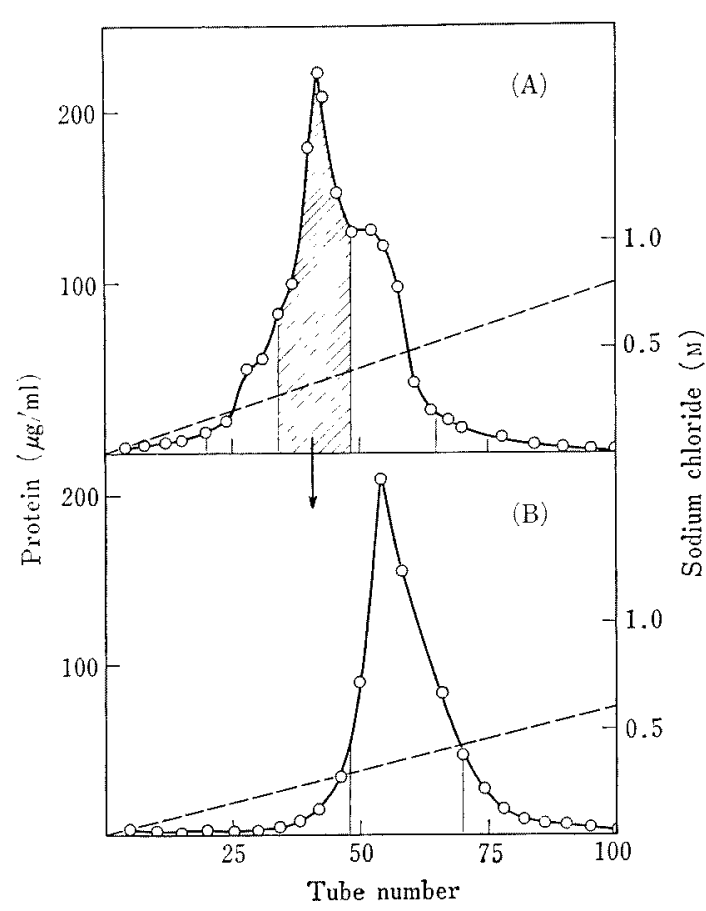

FIG. 2. Chromatography of Preparation Nos. 3 and 5 on a DEAE-cellulose Column.

O-O protein concentration, -..concentration of sodium chloride in $0.01 \mathrm{M}$ phosphate buffer of $\mathrm{pH}$ 7.0 .

3, about $120 \mathrm{ml}$ ) was added to a column $(2 \times 10 \mathrm{~cm})$ of DEAE-cellulose previously equilibrated with $0.01 \mathrm{M}$ phosphate buffer, pH 7.0, and the column was washed with the same buffer. Elution was carried out with a linear concentration gradient of sodium chloride in phosphate buffer; the mixer contained $250 \mathrm{ml}$ of $0.01 \mathrm{M}$ phosphate buffer, $\mathrm{pH} 7.0$, and the reservoir $250 \mathrm{ml}$ of $0.8 \mathrm{M}$ sodium chloride in the same buffer. Approximately $5 \mathrm{ml}$ per tube was collected. Figure $2 \mathrm{~A}$ shows the pattern of the protein eluted from the column. Tubes $20 \sim 34,35 \sim 48$ and $49 \sim 65$ were pooled separately and dialyzed against $0.01 \mathrm{M}$ phosphate buffer, $\mathrm{pH} 7.0$ (preparation Nos. 4, 5 and 6). Although oligogalacturonate transeliminase is powerfully inhibited by sodium chloride, its activity can be restored by dialysis of the enzyme solution. After the dialysis preparation Nos. 4, 5 and 6 were assayed for the enzyme activity. As shown in Table I most of the original enzyme activity was found in preparation No. 5.

Preparation No. 5 (prepared from about 240 $\mathrm{ml}$ of preparation No. 3 and brought to about $30 \mathrm{ml}$ by pervaporation and dialysis) was added to a column $(2 \times 10 \mathrm{~cm})$ prepared in the same manner as above. The enzyme was eluted with a concentration gradient of sodium chloride; the mixer contained $250 \mathrm{ml}$ of $0.01 \mathrm{M}$ phosphate buffer, $\mathrm{pH} 7.0$, and the reservoir $250 \mathrm{ml}$ of $0.6 \mathrm{M}$ sodium chloride in the same buffer (Fig. 2B). Tubes $48 \sim 70$ were collected and, after dialysis, concentrated at $4 \sim 5^{\circ} \mathrm{C}$ by pervaporation. The concentrate was dialyzed against $0.02 \mathrm{M}$ phosphate buffer, $\mathrm{pH} 7.0$, and used as purified enzyme solution (preparation No. 7). This preparation contains about $27 \%$ of the activity of the original extract and the

Table I. Summary of Purification Procedure

\begin{tabular}{|c|c|c|c|c|c|}
\hline $\begin{array}{c}\text { Enzyme preparation } \\
\text { No. }{ }^{a)}\end{array}$ & $\begin{array}{l}\text { Volume } \\
\text { (ml) }\end{array}$ & Total unit & $\begin{array}{l}\text { Total protein } \\
(\mathrm{mg})\end{array}$ & $\begin{array}{l}\text { Specific activity } \\
\text { (unit/mg) }\end{array}$ & $\begin{array}{c}\text { Recovery of enzyme } \\
(\%)\end{array}$ \\
\hline 1 & 418 & 11.40 & 80.26 & 0.14 & 100 \\
\hline 2 & 96 & 8.34 & 17.28 & 0.48 & 73.2 \\
\hline 3 & 121 & 7.60 & 15.24 & 0.50 & 66.7 \\
\hline 5 & 117 & 4.00 & 7.54 & 0.53 & 35.1 \\
\hline 7 & 6.8 & 3.10 & 5.64 & 0.55 & 27.2 \\
\hline 4 & 125 & 0.50 & 2.34 & 0.21 & 0.4 \\
\hline 6 & 131 & 1.53 & 4.80 & 0.32 & 13.4 \\
\hline
\end{tabular}

a) See the text. 
specific activity was increased about 4 fold (Table I).

\section{Properties of oligogalacturonate transeliminase}

Effect of $p H$ on enzyme activity. When 4,5unsaturated digalacturonic acid was used as substrate, the $\mathrm{pH}$ optimum was found to be at 7.0. With di-, tri- and tetragalacturonic acids as substrates the emzyme seems to display $\mathrm{pH}$ optima also at 7.0 (Fig. 3).

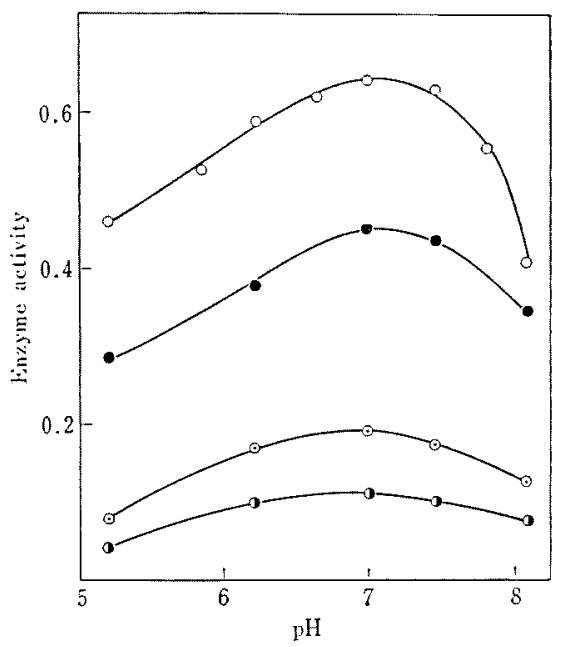

FIG. 3. pH-activity Curves.

Reaction mixture containing $0.05 \mathrm{M}$ phosphate buffer was incubated for $1 \mathrm{hr}$ (4,5-unsaturated digalacturonic acid, $\mathrm{O}-\mathrm{O}$ ) or $4 \mathrm{hr}$ (digalacturonic acid, - - ; trigalacturonic acid, $\odot-\odot$; tetragalacturonic acid, -o). Enzyme activity was determined by measuring the increase in reducing power (iodine-consumption, $0.002 \mathrm{~N}, \mathrm{ml} / 0.5 \mathrm{ml}$ ).

Time-course of enzyme action. Figure 4 shows the time-course of the enzyme action on 4,5unsaturated digalacturonic acid. The iodineconsumption increased and the absorption at $232 \mathrm{~m} \mu$ decreased in a linear manner: the reaction proceeded linearly for at least $150 \mathrm{~min}$.

Relation of enzyme concentration to enzyme activity. The enzyme activity toward 4,5unsaturated digalacturonic acid was proportional to the enzyme concentration (Fig. 5).

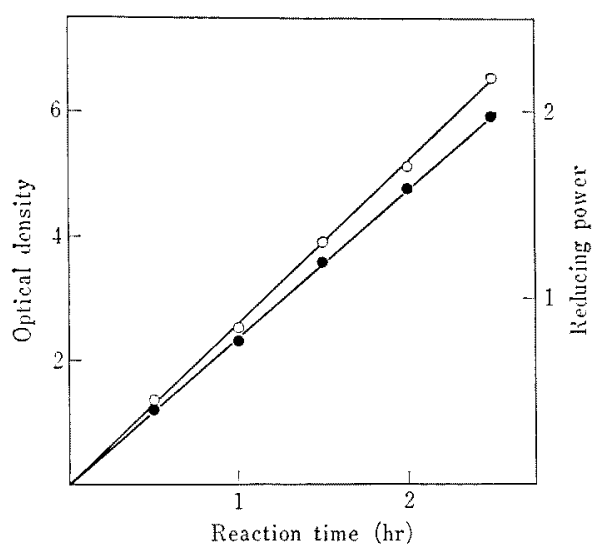

FIG. 4. Time-course of the Enzyme Action on 4,5Unsaturated Digalacturonic Acid.

About 0.5 unit of enzyme was used per $\mathrm{ml}$ of reaction mixture. $\mathrm{O}-\mathrm{O}$ decrease in optical density at $232 \mathrm{~m} \mu,-$ increase in reducing power (iodineconsumption, $0.002 \mathrm{~N}, \mathrm{ml} / 0.2 \mathrm{ml}$ ).

Enzymic degradation of trigalacturonic acid. No compounds giving absorption at $232 \mathrm{~m} \mu$, indicative of 4,5-unsaturation of uronic acids, were found in the reaction mixture. There are two glycosidic linkages in a trigalacturonic acid molecule. If the enzyme degraded the

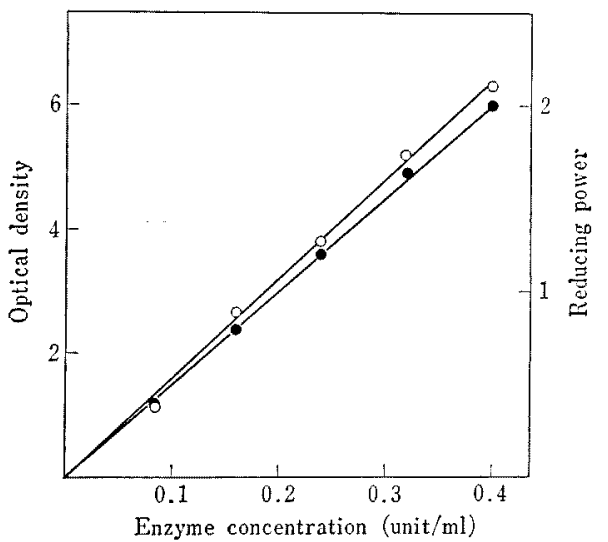

FIG. 5. Relation of Enzyme Concentration to the Enzyme Activity toward 4,5-Unsaturated Digalacturonic Acid.

Incubation, for $3 \mathrm{hr}$. Symbols are the same as described for Fig. 4. 


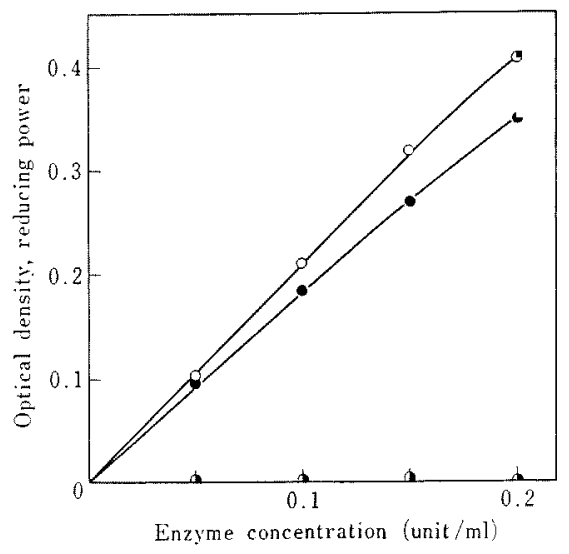

FIG. 6. Enzymic Degradation of Trigalacturonic Acid.

Incubation, for $4 \mathrm{hr} . \mathrm{O}-\mathrm{O}$ thiobarbituric acid test (optical density measured on a Hitachi photoelectric photometer with No. 55 filter), - increase in reducing power (iodine-consumption, $0.002 \mathrm{~N}$, $\mathrm{ml} / 0.5 \mathrm{ml}), 0$ increase in optical density at $232 \mathrm{~m} \mu(\times 1 / 11)$.

linkage adjacent to the terminal non-reducing residue by way of a transelimination, 4,5unsaturated digalacturonic acid and galacturonic acid would be formed. In contrast, the cleavage of the linkage adjacent to the reducing residue would result in the formation of digalacturonic acid and 4-deoxy-5-keto-D-fructuronic acid. The results in Fig. 6 support the latter mechanism.
Ratio of the enzyme activities toward oligo- and polygalacturonates. The enzyme preferentially attacked the short-chain uronides (Table II). Unsaturated oligo- and polygalacturonates were degraded more rapidly than the corresponding saturated uronides.

Enzymic degradation products. Paper chromatographic data in Table III confirm the conclusion drawn from Fig. 6 on the mode of the enzyme action. The detectable product of the enzyme action on 4,5-unsaturated digalacturonic acid was only 4-deoxy-5-keto-Dfructuronic acid. The formation of the latter from both the unsaturated and saturated galacturonic acid residues of 4,5-unsaturated digalacturonic acid suggests that the first product of the enzyme action on the substrates is 4,5-unsaturated galacturonic acid and this compound is converted into 4-deoxy-5-keto-Dfructuronic acid by an unknown mechanism.

The results obtained with preparation No. 4, the front part of the peak in Fig. $2 \mathrm{~A}$, indicates that this preparation contained an appreciable amount of digalacturonopolygalacturonase described in the previous paper. ${ }^{91}$ It seems possible that preparation No. 7, purified from the main peak in Fig. $2 \mathrm{~A}$, would contain a small amount of digalacturonopolygalacturonase and, for this cause, degrade high molecular pectic acid (Table III).

Table II. Ratio of the Enzyme Activities Toward Oligo- and Polygalacturonates

\begin{tabular}{lcccc}
\multicolumn{1}{c}{ Substrate } & $\mathrm{DP}^{a}$ of substrate & $\begin{array}{c}\text { Enzyme } \\
\text { concentration } \\
\text { (unit/ml) }\end{array}$ & $\begin{array}{c}\text { Thiobarbi- } \\
\text { turic acid } \\
\text { test } b \text { ) }\end{array}$ & Relative rate \\
\hline Acid-soluble pectic acid & 11.2 & 0.40 & 0.026 & 1 \\
Tetragalacturonic acid & 4 & 0.20 & 0.037 & 2.85 \\
Trigalacturonic acid & 3 & 0.20 & 0.092 & 7.08 \\
Digalacturonic acid & 2 & 0.10 & 0.082 & 12.62 \\
Unsaturated acid-soluble pectic acid & 16.2 & 0.20 & 0.052 & 4.00 \\
Unsaturated trigalacturonic acid & 3 & 0.10 & 0.131 & 21.83 \\
Unsaturated digalacturonic acid & 2 & 0.02 & 0.092 & 35.39 \\
\hline
\end{tabular}

Reaction mixture containing $2 \mathrm{~mm}$ substrate was incubated for $1 \mathrm{hr}$.

a) Degree of polymerization.

b) Optical density measured on a Hitachi photoelectric photometer with No. 55 filter.

c) Expressed as relative rates of bonds split by the same amount of enzyme. 
Table III. Paper Chromatographic Analysis of Degradation Products From OLIGo- AND POLYGalaCturonates

\begin{tabular}{|c|c|c|c|c|c|c|}
\hline \multirow[b]{2}{*}{ Substrate } & \multicolumn{6}{|c|}{ Products } \\
\hline & $\begin{array}{l}\text { Trigalac- } \\
\text { turonic } \\
\text { acid }\end{array}$ & $\begin{array}{l}\text { Digalac- } \\
\text { turonic } \\
\text { acid }\end{array}$ & $\begin{array}{l}\text { Unsaturated } \\
\text { digalacturonic } \\
\text { acid }\end{array}$ & $\begin{array}{l}\text { Galac- } \\
\text { turonic } \\
\text { acid }\end{array}$ & $\begin{array}{c}\text { 4-Deoxy- } \\
\text { 5-keto-D- } \\
\text { fructuronic acid }\end{array}$ & $\mathrm{X}^{a+1}$ \\
\hline Pectic acid & $(-)$ & $\begin{array}{c} \pm \\
(\mathbb{H})\end{array}$ & $\begin{array}{c}- \\
(-)\end{array}$ & $\begin{array}{c} \pm \\
(+)\end{array}$ & $\begin{array}{c} \pm \\
(+)\end{array}$ & $\begin{array}{c}- \\
(-)\end{array}$ \\
\hline Acid-soluble pectic acid & - & \pm & - & \pm & + & - \\
\hline Trigalacturonic acid & $H$ & H & - & + & $H$ & - \\
\hline Digalacturonic acid & - & $H$ & - & 世 & $H$ & - \\
\hline Unsaturated digalacturonic acid & - & - & \pm & - & H & \pm \\
\hline
\end{tabular}

Assay conditions: substrate $0.2 \%$; phosphate buffer, $0.02 \mathrm{M}, \mathrm{pH} 7.0$; enzyme, about 0.2 unit per ml; incubation, for $30 \mathrm{hr}$ at $30^{\circ} \mathrm{C}$.

About $0.03 \mathrm{ml}$ of reaction mixture was applied for paper chromatography.

The results presented in parentheses are those obtained with enzyme preparation No. 4 (see the text).

a) An unidentified substance.

TABle IV. INFLUENCE OF $\mathrm{CaCl}_{2}$ ON THE ENZYMiC DEgRADATION OF 4,5-UNSATURATED DigalaCtuRONIC ACID

\begin{tabular}{lc}
\hline $\begin{array}{l}\mathrm{CaCl}_{2} \\
(\mathrm{mM})\end{array}$ & $\begin{array}{c}\text { Todine-consumption } \\
(0.002 \mathrm{~N}, \mathrm{ml} / 0.5 \mathrm{ml})\end{array}$ \\
\hline 0 & 0.20 \\
0.1 & 0.20 \\
0.2 & 0.21 \\
0.5 & 0.20 \\
1.0 & 0.23 \\
\hline
\end{tabular}

Reaction mixture containing about 0.05 unit of enzyme per $\mathrm{ml}$ was incubated for $1 \mathrm{hr}$.

The enzyme did not require calcium ion for its activity (Table IV).

\section{DISCUSSION}

Although the enzyme described in the present paper may have a slight activity toward high molecular pectic acid, it preferentially attacks the short-chain uronides. In this respect this transeliminase differs from exopectate transeliminase reported in the previous papers. ${ }^{1-31}$ It was named oligogalacturonate transeliminase.

This enzyme degrades the unsaturated uronides more rapidly than the corresponding saturated uronides. For this reason it might be proper to call this enzyme unsaturated oligogalacturonate transeliminase.

From one mole of 4,5-unsaturated digalacturonic acid two moles of 4-deoxy-5-keto-Dfructuronic acid are produced by the enzyme action. The formation of the latter from both the unsaturated and saturated galacturonic acid residues of 4,5-unsaturated digalacturonic acid suggest that the first product of the enzyme action on the substrates is 4,5-unsaturated galacturonic acid. The process by which 4,5-unsaturated galacturonic acid is converted into 4-deoxy-5-keto-D-fructuronic acid is now under investigation in our laboratory.

This transeliminase attacks the first linkage from the reducing end of the substrate molecule. Exo-pectate transeliminase reported in the previous papers ${ }^{2,31}$ degrades the substrate also from the reducing end. These enzymes contrast markedly in this respect with exopolysaccharide hydrolases and glycosyltransferases, which degrade the substrates from the non-reducing ends. When the division of a polysaccharide molecule represented as $\mathrm{A}-\mathrm{O}-\mathrm{B}$ ( $A$ and $B$ contain non-reducing and reducing terminal residues, respectively) occurs on either side of the bridging oxygen atom, $\mathrm{A}-\mathrm{O}$ bond is 
broken by hydrolases and glycosyltransferases, and O-B bond by eliminases (lyases). ${ }^{141}$ From these facts and the results in the present and previous studies $^{31}$ it is possible to build up the following hypothesis:

The exo-polysaccharases splitting the bonds between the carbonyl carbon and the bridging oxygen (A-O) degrade the substrate molecules

14) J. Ludowieg, B. Vennesland and A. Dorfman, J. Biol. Chem., 236, 333 (1961). from the non-reducing ends, while those breaking the glycosidic bonds on the alcohol side of the oxygen bridge (O-B) decompose the substrates from the reducing ends.

This enzyme is the only known transeliminase that degrades the first glycosidic bond from the reducing end of the molecule of oligo- or polygalacturonates, forming a monosaccharide. It probably plays an important role in bacterial catabolism of oligo- and polygalacturonates. 